\title{
Nilai Pendidikan Dalam Tari Dewa Ayu Di Desa Pemuteran, Kecamatan Gerokgak, Kabupaten Buleleng
}

\author{
Ni Wayan Karmini ${ }^{1}$, I Wayan Diana ${ }^{2}$ \\ ${ }^{1}$ Universitas Hindu Indonesia, Denpasar \\ ${ }^{2}$ Sekolah Polisi Negara (SPN) Polda Bali, Singaraja \\ ${ }^{1}$ karmini@uhni.ac.id
}

\begin{abstract}
Abstact
This scientific work aims to discuss the procession of the dewa ayu dance and it's value of Hindu religious education contained in this dance. This scientific work is the result of qualitative research whose data was collected through observation, documentation studies and in-depth interviews with Pemuteran village traditional leaders and observers of Balinese culture. Data analysis was carried out qualitatively descriptive by applying a number of eclectic theories, namely aesthetic theory, symbol theory and constructivism theory. The results of the study show that the indigenous people of Pemuteran Village are trying to preserve the Dewa Ayu Dance as an offering to Hyang Widi Wasa at the Panca Yadnya Ceremony. In general, the procession of the god ayu dance can be divided into three parts (1) canang sari and incense offerings by stakeholders; (2) ngurek, which is the stage of the dancers who are accompanied by stakeholders who experience a disturbances by stabbing themselves with a dagger they carry; (3) the dancers' awareness stage from distress to the normal situation. Pemangku took a keris from a dancer to be given a tirta and brought to its place (innards). Dewa Ayu dance has educational values, including: the value of togetherness education, the value of tattwa education, the value of moral education, ceremonial education, and the educational value of appreciation of art and culture. As part of efforts to preserve guardian dance (sacred), the tradition of Dewa Ayu dance performances in the life of Pemuteran Village community needs to be preserved.
\end{abstract}

Keywords: Dewa Ayu Dance; Pemuteran Society; Hindu Education Values

\begin{abstract}
Abstrak
Karya ilmiah ini bertujuan membahas prosesi pertunjukan tari dewa ayu dan nilai pendidikan agama hindu yang terkandung di dalamnya. Karya ilmiah ini merupakan hasil penelitian kualitatif yang datanya dikumpulkan melalui observasi, studi dokumentasi dan wawancara mendalam dengan pemuka adat desa Pemuteran serta pemerhati budaya Bali. Analisis data dilakukan secara kualitatif deskriptif dengan menerapkan beberapa teori secara eklektik, yaitu teori estetika, teori simbol dan teori konstruktivisme. Hasil kajian menunjukkan bahwa masyarakat adat Desa Pemuteran berupaya melestarikan Tari Dewa Ayu sebagai persembahan kepada Hyang Widi Wasa pada Upacara Panca Yadnya. Secara umum, prosesi tari dewa ayu bisa dipilah menjadi tiga bagian (1) persembahan canang sari dan dupa oleh pemangku; (2) ngurek, yakni tahap penari yang didampingi pemangku mengalami kerauhan dengan menikam diri dengan keris yang mereka bawa; (3) tahap penyadaran penari dari kerauhan ke situasi normal. Pemangku mengambil keris dari penari untuk diberi tirta dan dibawa ke tempatnya (jeroan). Tari Dewa Ayu memiliki nilai-nilai pendidikan, meliputi: nilai pedidikan kebersamaan, nilai pendidikan tattwa, nilai pendidikan susila, pendidikan upacara, dan nilai pendidikan apresiasi seni dan budaya. Sebagai bagian dari upaya pelestarian tari wali (sakral), tradisi pertunjukan tari Dewa Ayu dalam kehidupan masyarakat Desa Pemuteran perlu tersu dilestarikan.
\end{abstract}

Kata Kunci: Tari dewa Ayu; Masyarakat Pemuteran; Nilai Pendidikan Agama Hindu 


\section{Pendahuan}

Dalam Tri Kerangka dasar Agama Hindu, aspek upacara (ritual) merupakan aspek yang lebih ekspresif (menonjol) dibandingkan dengan aspek tattwa (filsafat) dan susila (etika). Namun pada prinsipnya ketiga aspek tersebut merupakan satu-kesatuan yang saling menjiwai dan memberikan fungsi secara keseluruhan. Ketiga bagian tersebut merupakan satu kesatuan yang tidak dapat dipisahkan antara yang satu dan yang lainnya. Ketiganya ini meski dimiliki dan dilaksanakan oleh umat hindu. Tattwa adalah aspek pengetahuan agama atau ajaran-ajaran agama yang harus dimengerti daan dipahami oleh masyarakat terhadap aktivitas agama yang dilaksanakan. Susila adalah aspek pembentukan sikap keagamaan yang menuju pada sikap dan perilaku yang baik sehingga manusia memiliki kebajikan dan kebijaksanaan, wiweka jnana. Sementara itu acra adalah tata cara pelaksanaan ajaran agama yang diwujudkan dalam tradisi upacara sebagai wujud simbolis komunikasi manusia dengan Tuhanya. Seluruh rangkaian upacara dalam Agama Hindu pada dasarnya selalu dilandasi oleh etika agama, demikian pula halnya pelaksanaan etika tersebut dilandasi oleh tattwa agama.

Yadnya atau upacara dilaksanakan sesuai dengan filosofi (tattwa), etika (susila) dan fasilitas (upakara) dari yadnya upacara yang dilakukan. Sedangkan secara spiritual, yadnya berarti sungguh-sungguh, jujur, ketulusan dari dalam hati yang benar-benar mendalam oleh seseorang yang melaksanakan upacara yadnya. Yadnya bukanlah semata bersifat ritual, tetapi yang lebih penting Yadnya merupakan atau kerja simbolis yang dipahami sebagai suatu konsep dalam rangka jalan sublimasi diri. Yadnya yang dipersembahkan sesuai dengan hukum atau aturan kitab suci, serta tidak mengharapkan hasil atau balasan, ikhlas dan teguh dalam keyakinan, sebagai kewajiban-kewajiban, dianggap Yadnya atau korban yang baik (Satvika Yadnya). Setiap upacara (yadnya) yang dilakukan umat Hindu di Bali selalu menggunakan sarana. Sarana pokok adalah seperti air, api, bunga, buah (Wiana, 2002:55).

Selain itu yang lebih pamilier dalam umat Hindu di Bali adalah sarana dalam bentuk banten (upakara). Upakara adalah sesuatu yang sangat tidak asing bagi masyarakat Hindu umumnya dan khususnya di Bali. Setiap kegiatan yang berhungan dengan keagamaan selalu tidak terlepas dari upakara banten (uparengga). Bagi umat Hindu upakara merupakan sebuah simbol atau niyasa dari Tuhan dan pengharapan dari umat Hindu itu sendiri. Kita mengenal beberapa istilah yaitu Upasana, Upacara, Upakara, dan Uparengga.Upasana merupakan aturan-atuaran atau pedoman pelaksanaan persembahyangan, Upacara adalah bentuk ritual dan persembahyangan yang dilakukan oleh umat. Sedangkan Upakara berasal dari kata Upa yang berarti dekat dan kara berarti tangan. Jadi Upakara adalah sebuah sarana dalam sebuah upacara keagamaan yang dibuat dan diciptakan melalui hasil karya dari tangan. Selain daripada itu, yang dimaksud dengan uparengga adalah sarana dan prasarana dalam membuat upakara yang digunakan sebagai pelengkap suatu upakara. Setiap bagian masyarakat yang terkecil yaitu keluarga pasti tidak terlepas dari banten atau upakara dalam pelaksaan keagamaan. Upakara menjadi sarana utama dalam suatu kegiatan beragama atau beryadnya (Surayin, 2002:1).

Revolusi Industri 4.0 merupakan era yang diwarnai oleh kecerdasan buatan (artificial intelligence), era super komputer, rekayasa genetika, inovasi, dan perubahan cepat yang berdampak terhadap ekonomi, industri, pemerintahan, dan politik. Dalam era revolusi industri banyak mengubah cara kerja manusia dari penggunaan manual menjadi otomatisasi atau digitalisasi (BKSTI 2017). Memasuki era revolusi industri 4.0 dewasa ini, sebagian tradisi masyarakat nusantara mengalami kerapuhan dan ditinggalkan oleh pendukungnya. Namun, masyarakat Desa Pemuteran Buleleng justru masih mempertahankan tradisi nenek moyangnya, antara lain dengan mementaskan tari dewa ayu 
dalam upacara yadnya. Tari Dewa Yadnya merupakan tari wali, tari sacral untuk persembahan upacara (Bandem, 2004:1).

Tari Dewa Ayu (Medewa Ayu) merupakan tarian sakral sebagai Purwa Dresta yaitu kebiasaan-kebiasaan yang bersifat religius. Tari sacral ini senantiasa dipentaskan pada saat upacara Yadnya bagi warga Pemuteran Buleleng sebagai penetralisir alam semesta dari gangguan para bhuta kala yang belum mendapatkan sesaji/labaan. Tari Dewa Ayu merupakan ucapan puji syukur kehadapan Ida Sang Hyang Widhi Wasa yang dipentaskan ketika akhir dari pada rangkaian upacara yadnya.

Menurut penuturan warga setempat, sebelum tahun 1930 han warga Seraya Pan Baru dan Pan Mida datang ke daerah Pemuteran ketika itu daerah Pemuteran masih bernama Sumberkima. Tujuan Pan Baru dan Pan Mida datang kedaerah Pemuteran ketika itu bermaksud untuk membuka daerah baru sebagai tempat bercocok tanam (bertani) sekaligus untuk membuat tempat tinggal. Tidak semudah apa yang direncanakan oleh Pan Baru dan Pan Mida banyak hambatan yang dialami baik dari alam, binatang buas dan gangguan-gangguan gaib yang tidak dapat dipahami oleh Pan Baru dan Pan Mida. Sebelum Pan Baru dan Pan Mida datang ke daerah Pemuteran, terlebih dahulu sudah ada beberapa masyarakat dari daerah Banyuangi dan Madura yang berada di daerah Pemuteran namun mereka tidak bisa berbuat banyak karena situasi alam yang tidak mendukung.

Dari berbagai gangguan tersebut pan Mida dan Pan Baru teringat dengan tarian Dewa Ayu yang sudah membudaya dan di sakralkan oleh warga Seraya Karangasem. Karena dirinya merasa sebagai warga Seraya akhirnya mereka berdua merencanakan dan melaksanakan upacara Yadnya seadanya sesuai dengan kemampuan serta keyakinan dan dipentaskannya tari Dewa Ayau (medewa Ayu) seadanya, karena tari Dewa Ayu banyak mistik. Dengan dilaksanakannya tari sakral Dewa Ayu Pan Baru dan Pan Mida beserta warga lainnya mulai merasakan adanya perubahan gangguan mulai berkurang, merasakan adanya kenyamanan, alam, binatang dan gangguan gaib berangsur-angsur tidak dirasakan lagi. Pan Mida dan Pan Baru beserta warga yang ada di daerah Pemuteran berangsurangsur dapat melaksanakan aktivitas dengan lancar sesuai dengan harapan warga Pemuteran.

Warga Pemuteran merasa terselamatkan dengan adanya tari Dewa Ayu, karena tari Dewa Ayu diyakini sebagai tari sakral yang dapat menghubungkan alam Sekala dengan alam Niskala, dengan alam lingkungan daerah pemutera dan dengan mahluk hidup (binatang) yang hidup liar di daerah hutan Pemuteran sehingga masyarakat dapat hidup dan beraktivitas didaerah Pemuteran dengan baik tanpa adanya perasaan was-was. Ketika gunung Agung meletus (erupsi) pada tahun 1963, warga Karangasem Seraya semakin banyak bertadangan menyelamatkan diri mengungsi ke daerah Bali Utara tepatnya di Desa Pemuteran, karena para warga Seraya teringat dengan beberapa warganya (semeton) Seraya sudah ada di daerah Pemuteran jauh sebelum terjadinya letusan gunung Agung.

Dengan semakin banyaknya warga Seraya berada didaerah Gerokgak tepatnya Desa Pemuteran tari Dewa Ayu disakralkan dan diwariskan secara turun temurun sampai sekarang di lestarikan oleh warga pemuteran khususnya warga Pemuteran yang berasal dari Karangasem Seraya. Makalah ini akan membahas tiga permasalahan: (1) Mengapakah Tari Dewa Ayu sampai saat ini dilestarikan oleh warga di Desa Pemuteran, Kecamatan Gerokgak, Kabupaten Buleleng?, (2) Bagaimanakah prosesi pertunjukan Tari Dewa Ayu tersebut?, dan (3) Nilai Pendidikan Agama Hindu apa saja yang terkandung dalamnya?. Diharapkan, publikasi ini bermanfaat untuk mengetahui fungsi dan makna tari Dewa Ayu dan nilai-nilai pendidikan yang terkandung dalam prosesi tarian Dewa Ayu di Desa Pemuteran, Buleleng. 


\section{Metode}

Karya ilmiah ini merupakan hasil penelitian seni-budaya, khususnya tari Dewa Ayu di Desa Pemuteran, Kecamatan Gerokgak, Kabupaten Buleleng. Data penelitian diperoleh melalui: (a) studi dokumentasi yakni dokumen (bahan bacaan) atau data tertulis yang terkait dengan topik penelitian; (b) pengamatan langsung di lapangan, ketika pementasan tari Dewa Ayu pada Upacara Panca Yadnya di Desa Pemuteran, Kecamatan Gerokgak, Kabupaten Buleleng, serta (c) wawancara mendalam dengan 10 informan, yakni dengan penyusngsung tari dewa ayu, serta dengan pemuka agama Hindu setempat dan pemerhati seni-budaya Bali. Analisis data dilakukan secara kualitatif deskriptif dengan menerapkan beberapa teori secara eklektis, yaitu teori estetika, teori simbol dan teori konstruktivisme.

\section{Hasil dan Pembahasan}

\section{Proses Pertunjukan Tari Dewa Ayu}

Desa Pemuteran adalah desa yang berada di Kecamatan Gerokgak, Kabupaten Buleleng. Sebagian warga masyarakat Desa Pemuteran dan Kecamatan Gerokgak pada umumnya berasal dari Seraya Karangasem yang memiliki tradisi mementaskan tari Dewa Ayu dalam setiap pelaksanaan Upacara Yadnya. Pelenggarakan upacara Panca Yadnya belum dinyatakan lengkap apabila belum nyolahang tari Dewa Ayu.Setiap karya (upacara) yadnya di Pura Desa, Pura Segara, Pura Dalem tari Dewa Ayu selalu di pentaskan. Masyarakat Desa Pemutaran meyakini bahwa pementasan tari Dewa Ayu merupakan bagian dari persembahan ke hadapan Ida Sang Hyang Widi Wasa yang telah memberikan memberikan perlindungan, keselamatan, kekuatan, kesejahtraan dan kebahagian hidup.

Pementasan tari dewa ayu merupakan upaya untuk melihara hubungan yang harmonis antara manusia selaku mikrokosmos dengan alam semesta selaku makrokosmos. Dengan memelihara hubungan harmonis dengan alam ini, masyarakat Desa Pemuteran meyakini bahwa mereka akan diberiakn keselamatan dan dijauhkan dari malapetaka yang mengancam kehidupan mereka. Dalam kaitan ini, sebagaimana kata Sedyawati (2006 : 293), seni termasuk seni tari dewa ayu memliki fungsi religius, peneguhan integrasi sosial, edukatif dan hiburan.Tari Dewa Ayu di Desa Pemuteran yang dipentaskan untuk kepentingan upacara agama.Tempat pementasan tari Dewa Ayu ini adalah di halaman tengah (jaba tengah) tari ini dipentaskan di semua pura yang ada di Desa Pemuteran antara lain Pura Desa, Pura Segara, Pura Bukit Teledu, Pura Batu, dan Pura Dalem. Prosesi pementasan tari wali dewa ayu diawali dengan persembahan sarana base tampina kepada Ida Betara untuk menyertai pementasan tari Dewa Ayu. Base tampinan akan diberikan sebelum para penari mulai menari, tujuannya untuk menyucikan badan penari yang akan dimasuki oleh roh para dewa.Secara umum, prosesi tari dewa ayu bisa dipilah menjadi tiga bagian.

\section{a. Bagian Pertama:}

Tari Dewa Ayu dipentaskan pada saat persembahyangan telah selesai. Tari ini diawali oleh beberapa orang pemangkumemendet dengan membawa canang sari dan dupa. Pada bagian ini ada beberapa pemangku yang kerauhan (tidak sadarkan diri), setelah para pemangku itu menari akan diikuti oleh pemedek-pemedek lainnya. Mereka akan ikut menari-nari dengan membawa canang sari dan dupa, mereka menari dengan keadaan mata tertutup, dan semua menari mengikuti gambelan dari sekaa degdeg yang ada. 


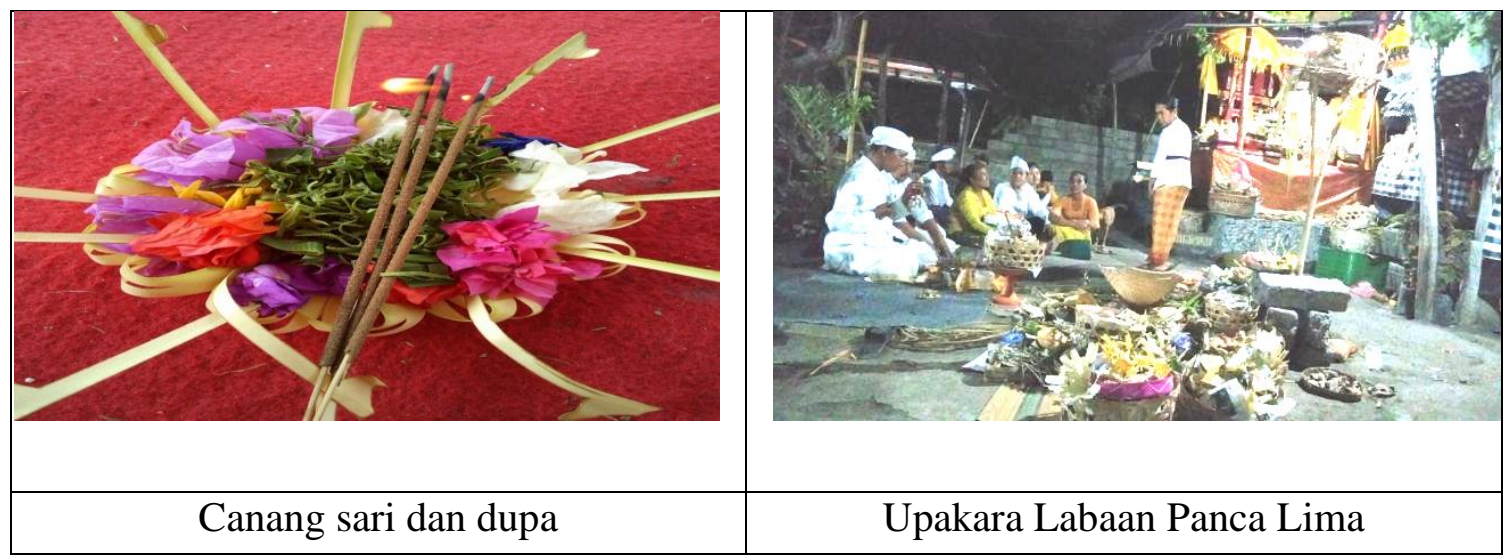

Gambar 1: Bagian dari sarana upakara untuk pementasan tari dewa ayu

\section{b. Bagian kedua:}

Selama mereka menari, satu persatu dari mereka mulai kerauhan dan diambilkanlah sebuah keris oleh jero mangku. Mereka akan menari dengan menikam keris itu ke dada mereka atau disebut ngurek. Dalam keadaan itu penari sudah tidak sadarkan diri dan kadang-kadang ada penari yang tidak cukup hanya menggunakan satu buah keris melainkan dua keris ditancapkan ke dada penari. Saat adegan ngurek ini tempo gambelan akan lebih cepat dan keras, para penari akan berhenti menari jika penari itu sudah melepaskan kerisnya dari dada dan mengarahkannya ke atas seperti orang menyembah dan keris itu akan di ambil oleh jero mangku, agar keris tersebut tidak jatuh ke tanah. Dikatakan kerisitu tidak boleh jatuh karena kalau sampai jatuh akan terjadi bencana.

\section{c. Bagian ketiga :}

Setelah keris itu diarahkan ke atas yang artinya penari itu sudah berhenti menari, keris ini akan diambil oleh pemangku dan di bawa ke jeroan untuk kembali diberi tirta, sama halnya juga dengan penarinya sesudah melakukan adegan ngurek dalam kondisi trance akan di bawa ke jeroan untuk diberikan tirta agar kembali sadar seperti awalnya. Kadang-kadang ada juga beberapa penari yang sudah diberikan tirta dan tidak sadarkan diri juga, ini dikatakan ada roh yang tidak mau keluar dari diri penari, dan pemangku akan membiarkan penari ini untuk kembali menari, dan tidak menggunakan keris hanya menarimenari biasa seperti memendetmengikuti gamelan yang ada, dan dalam kondisi seperti ini pemangku akan memberi isyarat kepada penabuh untuk memberikan tabuh Baris Tunggal, penari ini akan mengikuti iringan tabuh yang ada dan dengan sendirinya penari ini akan terjatuh dan kemudian para pemangku membawanya ke jeroan dan memberi tirta dan itu menjadi akhir dari pementasan tari Dewa Ayu ini.

Tari dewa ayu bisa dipentaskan bilamana telah dipenuhi beberapa persyaratannya, meliputi: adanya penari, ragam gerak tari, tata rias dan kostum, gamelan atau muisik pengiring, serta sesaji dan proferti (sarana) yang digunakan.

\section{1). Pertama.}

Penari Tari Dewa Ayu di Desa Pemuteran adalah siapa saja, tetapi apabila ditarikan oleh masyarakat Seraya akan ada adegan trace (kerauhan), dan apabila ditarikan oleh masyarakat yang bukan asli Seraya mereka tidak akan kerauhan. Penari dari Tari Dewa Ayu ini tidak ditentukan karena tarian ini merupakan tarian masal.

\section{2). Kedua}

Ragam gerak tari dewa ayu adalah suatu motif, jenis gerakan tari. Ragam gerakan tari ini jika disusun menjadi suatu kalimat gerak akan dapat memberikan arti atau makna bahkan mengandung sebuah maksud tertentu. Terkait dengan hal di atas, dari hasil pengamatan terhadap tari Dewa Ayu tampak ragam gerak yang membangun tarian ini lebih 
banyak terdiri dari gerakan tari murni, yang dilakukan secara sederhana dan berulangulang. Beberapa ragam gerak yang membangun tari Dewa Ayu ini adalah sebagai berikut: a). Ngegol adalah gerakan pinggul yang digoyangkan ke kiri dan ke kanan, gerakan ini dalam pementasan tari Dewa Ayu akan dilakukan berulang-ulang.

b). Gerakan melentangkan tangan kanan dan kiri secara bergantian dengan memegang canang sari dilakukan berulang-ulang selama penari Dewa Ayu belum kerasukan

c). Gerakan ngegol sambil memegang keris dengan kedua tangan posisi keris berada di atas kepala penari.

d). Adegan ngurek, penari akan menikamkan keris kedada dengan kedua tanganya, posisi keris tepat di depan dada penari.

e). Gerakan mengarahkan keris ke atas, seperti orang menyembah pada posisi seperti ini ujung keris akan mengarah ke atas.

\section{3). Ketiga}

Tata rias dan busana dalam seni pertunjukan selain berfungsi memperindah, memperkuat karakter juga menunjang nilai-nilai filosofis, dan nilai simbolik dalam tarian tersebut. Dalam pementasan seni tari khususnya seni tari Bali, elemen tata rias kostum sangat diperlukan dan juga sangat penting, misalnya dengan melihat tata riasnya bisa dibedakan tari tersebut dengan tarian lainnya.

Dengan perkembangan teknologi di jaman modern ini banyak seni pertunjukan menggunakan kostum maupun tata rias yang sangat mewah. Akan tetapi hal tersebut sangat berbeda dengan Tari Dewa Ayu, karena apabila dilihat dari segi kostum dan tata rias tarian ini sangat sederhana. Kostum yang digunakan oleh para penari sangatlah sederhana, karena hanya menggunakan pakaian adat ke pura, yaitu mengenakan baju kebaya, selendang, dan kamen (kain).

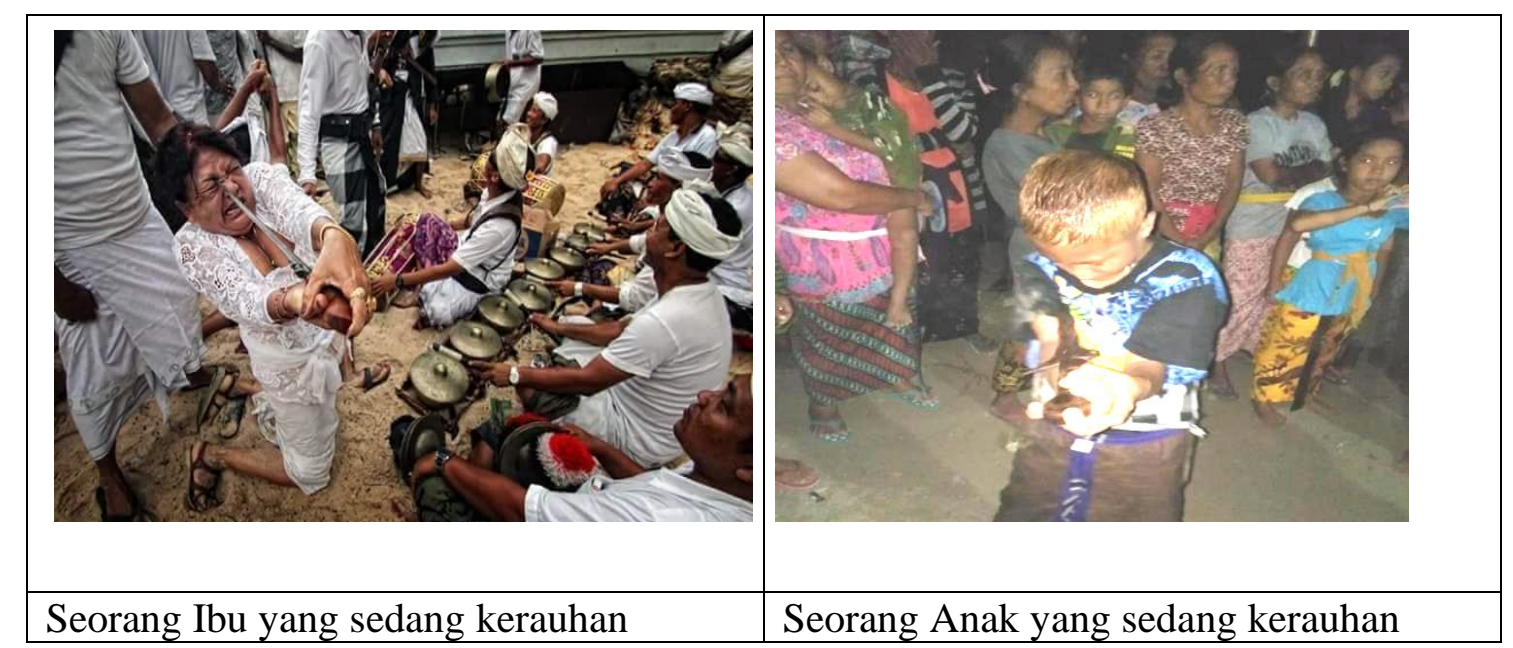

Gambar 2: Kerauhan sebagai Ciri khas tari Dewa Ayu

\section{4). Keempat}

Tari Dewa Ayu diiringi oleh beberapa alat musik seperti: Gangsa, Kenok, Cengceng, Kendang, Barangan/reong, Kempul, gong. Penabuh tari Dewa Ayu ini sebagian besar adalah masyarakat Desa Pemuteran, yang tergabung dalam suatu organisasi yang mereka beri nama sekaa degdeg, sekaa degdeg ini dipelopori oleh Ketut Werdika yang merupakan masyarakat pemuteran. Ketut Werdika juga menuturkan, sebelum adanya sekaa degdeg sebagai pengiringnya, awalnya tari Dewa Ayu ini diiringin dengan sulingan, ada beberapa macam jenis gending atau lagu yang digunakan pada saat pementasan tari Dewa Ayu ini seperti, rejang, gandrung,unyil, dan kincang- kincung, namun dikatakan juga dari sekian gending yang ada yang paling popular adalah gending gandrung. Sekaa 
degdeg ini terdiri dari 15 orang sekaha tetap, namun ada juga sekaha yang disewa karena terkadang ada anggota sekaha yang tidak hadir jadi harus mencari pengganti.

\section{5). Kelima}

Sesaji merupakan sarana persembahan yang dihaturkan masyarakat setempat kepada Ida Sang Hyang Widi Wasa.Pementasan tari Dewa Ayu diawali dengan menghanturkan sesaji berupa banten paneman. Dalam menghaturkan banten ini pemangku akan menyebut beberapa nama-nama Dewa yang merupakan sungsungan seperti berikut: Dewa Gede di kemulan, Dewa Gede Kangin, Dewa Gede tengahin Segare, Dewa, Gede Ratu di Dalem, Dewa Gede Puseh Kelodan, Dewa Gede Puseh Penataran.Banten paneman merupakan bantem pokok dalam tari Dewa Ayu. Banten paneman tersebut terdiri dari : banten peneduhan, sayut 2 tanding, peras 1 buah, banten gibungan, rantasan, sagi gede, tehenan, dan jejahitan legongan.

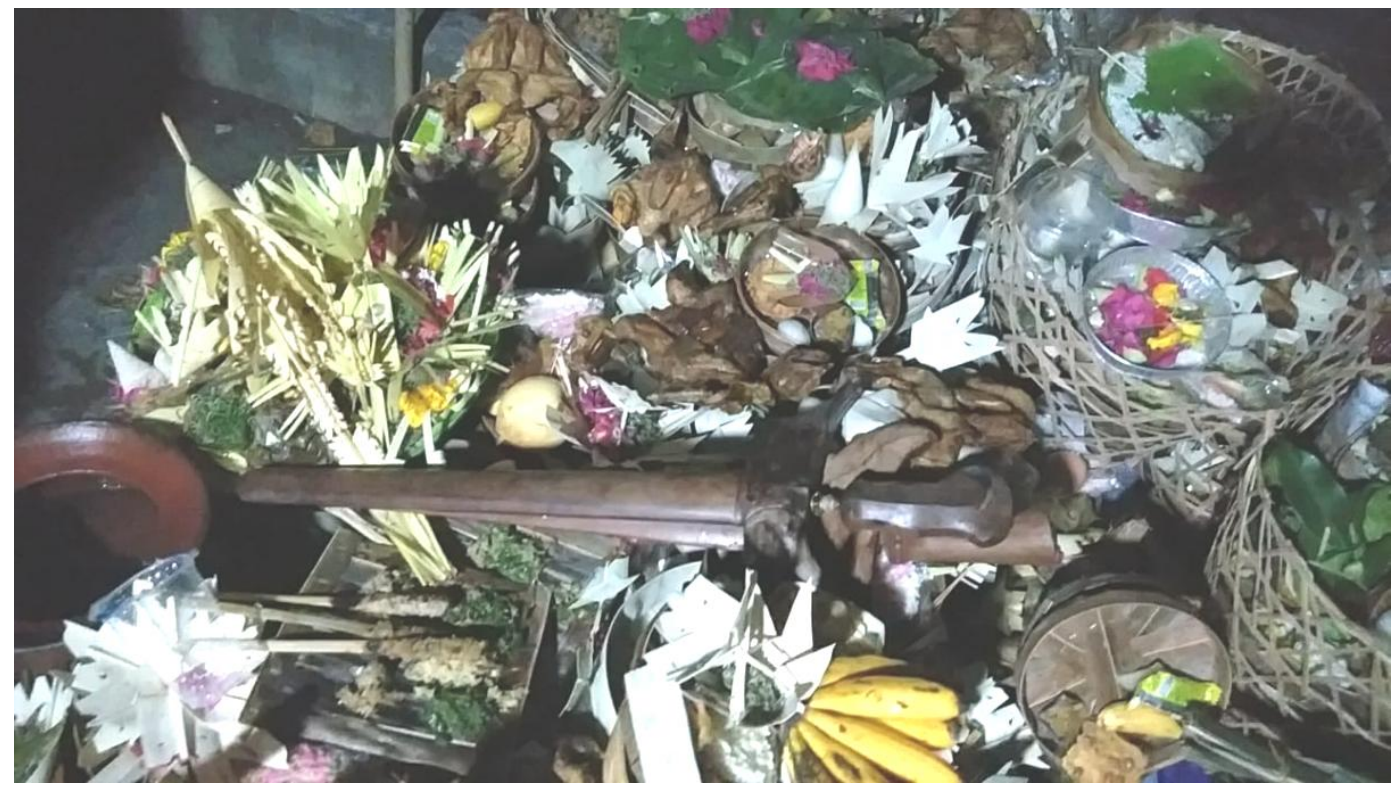

Gambar 3: Banten Peneman Yang merupakan

Banten pokok dalam Tari Dewa Ayu

(Dokumen: Sukerti,2018)

\section{6). Keenam}

Pementasan tari Dewa Ayu ini menggunakan properti yaitu keris atau yang sering disebut oleh masyarakat di Desa Pemuteran dengan istilah kadutan. Keris adalah sejenis pedang pendek yang berasal dari pulau jawa, Indonesia. Keris purba telah digunakan antara abad ke 9 dan 14. Selain digunakan sebagai senjata, keris juga dianggap memiliki kekuatan supranatural, magis, gaib. Keris dibuat dari 3 (tiga) unsur besi yaitu besi putih, besi merah, besi hitam yang melambang Tri Murti bila menunggal menjadi "Om". Keris juga melambangkan "lingga" (Purusa), sarungnnya melambangkan "Yoni" (Predana) namun didalam tari Dewa Ayu penari disimbulkan sebagai Predana. Lingga Yoni merupakan lambang kesuburan, kesejahtraan, kebahagiaan, keris juga diyakini sebagai pemarisudha (penyucian) roh jahat sehingga memiliki sifat Dewa (Geriya dkk 10).

\section{Nilai Pendidikan Dalam Prosesi Tari Dewa Ayu}

Tari Dewa Ayu ini dipentaskan pada upacara piodalan di pura-pura Desa Pemuteran. Masyarakat Desa Pemuteran selalu mementaskan tari Dewa Ayu ini pada setiap odalan diakhir persembahnyangan sebagai ucapan puji syukur karena pelaksanaan odalan di pura telah berjalan dengan baik. Pada saat pementasan tari Dewa Ayu ini biasanya seluruh pemedek yang berada di pura akan berkumpul ke tempat pementasan. 
Pada saat inilah mereka akan bertegur sapa antara masyarakat satu dengan yang lain, yang sudah lama tidak bertemu karena kesibukan bekerja. Di sini, tari dewa ayu memiliki fungsi religius sekaligus berfungsi sebagai integrasi sosial seperti media komunikasi. Rasa persaudaraan antara keluarga dan masyarakat Desa Pemuteran semakin kokoh.

Sebagai tari wali, Tari Dewa Ayu pada Upacara Panca Yadnya di Desa Pemuteran mengandung nilai-nilai Pendidikan Agama Hindu, sebagai berikut:

\section{a. Pendidikan Kebersamaan}

Untuk menjalin kerja sama dan keharmonisan diperlukan ketulusan hati dan kehalusan jiwa. Dari jiwa yang halus akan mengurangi sifat-sifat yang kasar dan keras. Kehalusan budhi merupakan pedoman untuk mendapatkan rasa kebersamaan. Dalam kebersamaan ini akan mendapatkan rasa kasih sayang yang mendalam, dari rasa keindahan, niat suci berdasarkan dharma akan memancarkan kasih sayang yang tulus dari lubuk hati yang paling dalam. Pendidikan keindahan dan kebersamaan yang bersifat religius adalah sebagai alat perekat untuk menumbuhkan rasa kasih sayang, membangun jiwa dengan sikap yang lembut sehingga perilaku masyarakat menjadi lebih tenang, damai dan pada akhirnya akan dapat melaksanakan ajaran Tri Kaya Parisudha yaitu berpikir, berkata dan berbuat atas dasar kesadaran budhi dengan daya nalar yang rasional. I Nyoman Arnawa (kelian Banjar) Desa Pekraman Pemuteran menyatakan sebagai berikut.

Nilai Pendidikan Kebersamaan Hubungannya dengan Tari Dewa Ayu adalah pada saat akan pementasan Tari Dewa Ayu, para penari yang terdiri dari berbagai warga/soroh ini secara bersama-sama menari dan saling bahu-membahu dalam membuat banten/sarana untuk pementasan Tari Dewa Ayu. Seluruh warga melaksanakan "Prasadham" makan bersama (megibung) ala budaya Karangasem Sehingga timbul rasa kebersamaan dan persatuan antara sesama penari yang tidak dilatih secara khusus dan warga merasa dekat antara yang satu dengan yang lainnya seolah-olah tidak ada pemisah. Kedekatan inilah yang menumbuhkan kenyamanan, keamanan dan persatuan dalam membangun dan memajukan Desa Pemuteran hingga bertumbuh kembang sampai saat ini yang dirasakan adanya peningkatan kesejahtraan dan kebahagiaan oleh warga masyarakat Desa Pemuteran (wawancara 15 Desember 2019).

Kebersamaan masyarakat Desa Pemuteran tersebut sesuai dengan Teori Konstruktivisme bahwa pembelajaran yang bersifat generatif, yaitu tindakan mencipta sesuatu makna dari apa yang dipelajari. Pementasan tari Dewa Ayu bisa merekatkan persaudaraan masyarakat adat Desa Pemuteran.

\section{b. Pendidikan Tattwa}

Tattwa artinya kebenaran, kebenaran yang mencakup hakekat Tuhan dalam alam semesta. Di Bali tattwa digunakan untuk menyatakan kebenaran itu.Cara memandang kebenaran itu berbeda-beda, perbedaan pandangan itulah yang menyebabkan adanya pengetahuan tentang tattwa berbeda-beda pula. Dalam buku Etika Hindu dan Perilaku Organisasi bahwa "tatwa merupakan uraian filosofi tentang ajaran-ajaran yang tersimpul dalam Panca Sradha" (Gorda,1996:30). Unsur pendidikan Tatwa (filsafat) dalam upacara Agama Hindu menyangkut tentang ajaran Panca Sradha. Tetapi tidak semua pembagian dari Panca Sradha yang dapat dihubungkan dengan nilai pendidikan tattwa dalam Tari Dewa Ayu.Yang ada hubungannya dengan Tari Dewa Ayu adalah nilai pendidikan tattwa dari segi kepercayaan terhadap Brahman dan kepercayaan terhadap Karma phala. Dengan demikian pengungkapan nilai pendidikan tatwa (filsafat) dalam Tari Dewa Ayu pada Upacara Yadnya di Desa Pemuteran adalah sebagai berikut :

Kepercayaan dan keyakinan umat manusia yang mendalam terhadap keberadaan Tuhan beserta manifestasi-Nya (Widhi Sradha), menjadi landasan konseptual bagi umat Hindu untuk melaksanakan Yadnya sebagai perwujudan cetusan rasa bhakti umat manusia 
kepada Ida Sang Hyang Widhi Wasa. Hubungannya dengan Tari Dewa Ayu adalah salah satu bentuk sarana persembahan kepada Ida Sang Hyang Widhi Wasa beserta manifestasiNya sebagai pelengkap dalam upacara Piodalan di Pura Puseh Desa Pakraman Culik Tari Lelegongan sebagai Pelengkap Upacara Yadnya merupakan suatu wujud keyakinan warga masyarakat kepada Ida Sang Hyang Widhi Wasa untuk mendapatkan keselamatan dan kerahayuan. Dalam kaitan ini, Jro Ketut Ayu pemuka adat Desa Pemuteran amenyatakan:

Dari salah satu warga masyarakat ada yang tidak mengaku wit (asalnya) dari Seraya, setiap melaksanakan Upacara Panca Yadnya tidak pernah mau nyolahang (mementaskan) Tari Dewa Ayu karena tidak meyakininya. Lama kelamaan warga tersebut mengalami berbagai musibah, keluarganya tidak harmonis, rejekinya tidak lancar dan merasakan kesusahan tiada hentinya. Sesuai dengan keyakinan warga tesebut akhirnya menanyakan kepada orang pintar tentang apa yang mereka alami saat itu. Dari situlah mereka baru menyadari bahwa mereka memang tidak pernah mementaskan tari Dewa Ayu setiap melaksanakan Upacara Panca Yadnya (wawancara, 11 Desember 2019).

Berawal dari hal itulah warga tersebut akhirnya menyanggupi setiap punya Acara Yadnya akan mementaskan tari Dewa Ayu. Lambat laun warga tersebut berangsur-angsur tidak lagi merasakan adanya gangguan, musibah serta halangan-halangan lainnya. Pandita Empu Putra Dwija Dharma Seraya mengatakan bahwa tari Dewa Ayu itu juga merupakan obat. Pernyataan tersebut diatas di dukung oleh Teori Konstruktivisme didefinisikan sebagai pembelajaran yang bersifat generatif, yaitu tindakan mencipta sesuatu makna dari apa yang dipelajari. Dalam melangsungkan hidupnya, umat manusia senantiasa melakukan bermacam-macam gerak dan aktivitas guna untuk memenuhi kebutuhan hidupnya.Segala macam gerak dan aktivitas tersebut dilakukan dengan cara baik atau tidak baik, secara sadar maupun tidak sadar. Menurut hukum alam segala macam sebab pastilah akan menimbulkan akibat. Demikian halnya suatu sebab yang berupa perbuatan pasti akan menimbulkan akibat berupa hasil perbuatan.

Hukum rantai sebab akibat atau hasil perbuatan dalam ajaran Agama Hindu disebut dengan karma phala. Dari uraian tersebut, dapat diungkapkan bahwa karma phala merupakan hukum sebab-akibat, siapa yang berbuat, maka secara otomatis mereka akan menikmati hasilnya. Baik buruknya perbuatan (karma) sangat menentukan baik buruknya hasil (phala). Kepercayaan dan keyakinan karma phala, menjadi dasar keimanan yang amat penting berpengaruhnya bagi sikap perilaku umat Hindu dalam segala kehidupannya.Hal ini mendorong setiap umat selalu berbuat berdasarkan dharma. Demikian juga, ditinjau aspek kepercayaan dan keyakinan terhadap karma phala, hubungannya dengan Tari Dewa Ayu adalah para penari percaya bahwa segala yang dilaksanakan atau dilakukan pasti memeperoleh hasil, mereka menari Tari Dewa Ayu secara tidah sadar namun dengan keikhlasan sebagai pelengkap upacara Panca Yadnya pasti nantinya memeperoleh hasil, baik di dunia maupun di akhirat.

\section{c. Pendidikan Susila.}

Etika/susila merupakan bagian dari kerangka dasar Agama Hindu. Dalam etika/susila diajarkan untuk menentukan perbedaan perbuatan yang baik dan mana perbuatan yang buruk. Etika adalah bentuk pengendalian diri dalam pergaulan hidup bersama. Seseorang harus mengatur dirinya bertingkah laku dan menyesuaikan dirinya dengan lingkungan serta tunduk kepada aturan bertingkah laku yang berlaku. Etika memuat pengetahuan tentang kesusilaan. Kesusilaan berbentuk kaidah-kaidah yang berisikan larangan-larangan atau suruhan-suruhan untuk berbuat sesuatu. Dalam etika juga akan tercermin ajaran perbuatan yang baik dan buruk. Perbuatan yang baik itulah mesti diikuti dan perbuatan yang buruk harus dihindari (Sudharta, 2002). 
Etika dalam ajaran Hindu termuat di dalam berbagai sastra suci Weda, Itihasa serta lontar-lontar yang ada di Bali.Terkait dengan pelaksanaan Tari Dewa Ayu Pada Upacara Panca Yadnya jika dihubungkan dengan pendidikan etika sangat erat. Hubungan tersebut telah mentradisi sejak dulu sampai sekarang. Salah seorang pemuka adat setempat, Ida Pandita Empu Putra Dwija Dharma Seraya menyatakan:

Dengan timbulnya kepercayaan masyarakat Desa Pemuteran akan Tari Dewa Ayu, maka pada akhir dari Upacara pasti nyolahang tari Dewa Ayu. Pementasan Tari Dewa Ayu sebagai Pelengkap Upacara Yadnya, menyadarkan masyarakat akan nilai seni dan keindahan untuk selalu mengendalikan diri agar jangan sampai lupa terhadap kebenaran dan melakukan perbuatan yang sesuai dengan tata susila dan etika (wawancara, tanggal 30 Oktober 2019).

Pernyataan tersebut diatas di dukung oleh Teori estetika adalah ilmu yang mempelajari segala sesuatu yang berkaitan dengan nilai-nilai keindahan, mempelajari semua aspek keindahan dalam seni dan alam. Djelantik dalam bukunya berjudul Estetika : Sebuah Penghantar, (1999) menyatakan bahwa yang dimaksud keindahan meliputi keindahan alam dan keindahan buatan manusia. Keindahan buatan manusia pada umumnya kita sebut kesenian. Dengan demikian kesenian, dapat dikatakan salah satu wadah yang mengandung unsur-unsur keindahan. Unsur- unsur keindahan mengandung tiga aspek dasar, yaitu:1) wujud, 2) bobot, dan 3) penampilan (Djelantik, 1999 : 17).

Wujud mengacu pada kenyataan yang tampak secara kongkrit (nyata) maupun kenyataan. Bobot dari benda atau peristiwa kesenian meliputi bukan hanya yang dilihat semata-mata tetapi juga apa yang dirasakan atau dihayati sebagai makna dari wujud kesenian itu. Penampilan adalah bagaimana cara kesenian disajikan atau disuguhkan kepada penikmatnya.

\section{d. Pendidikan Upacara}

Upacara berarti aktivitas manusia dalam menghubungkan diri dengan Ida Sang Hyang Widhi Wasa atau Tuhan Yang Maha Esa. Manusia merupakan mahluk ciptaan Tuhan yang paling utama dan mulia. Manusia juga berbudaya dan memiliki kelebihan dengan mahluk ciptaan Tuhan yang lainnya (Koentjraningrat,1993 :5).

Bagi manusia sudah merupakan suatu kewajiban untuk menghormati segala sesuatu yang telah diciptakannya dengan cara melaksanakan upacara yadnya untuk keseimbangan alam semesta. Cetusan rasa hormat dapat dilaksanakan dengan berbhakti kepada Tuhan. Dalam upacara manusia yadnya pawiwahan (perkawinan) misalnya, manusia juga melakukan puja bhakti kepada Hyang Widi Wasa (Gambar 6).

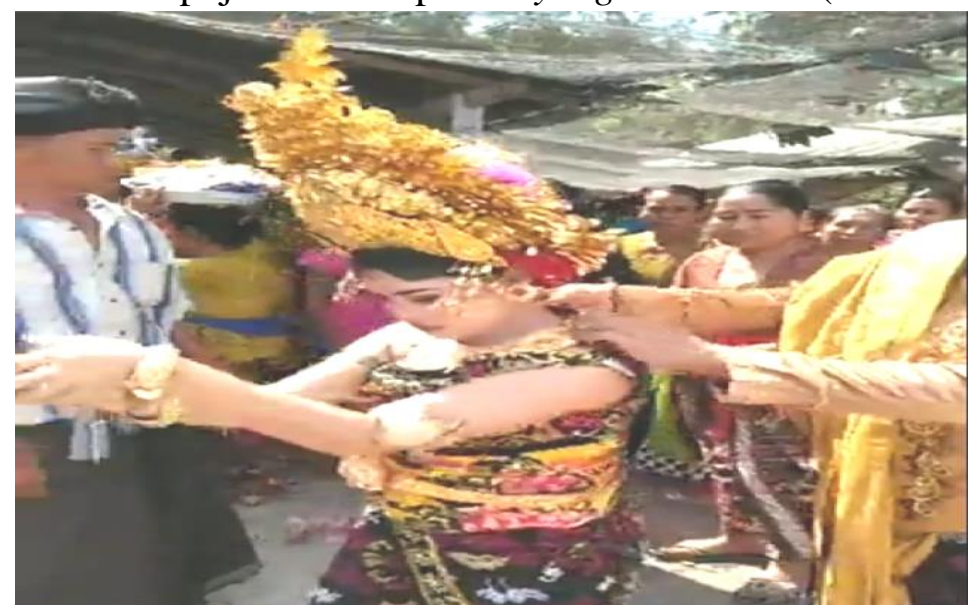

Gambar 5

Penganten putri turut kerauhan saat upacara Pawiwahan (Manusa Yadnya)

(Dokumen: Sukerti, 2018) 
Dalam mewujudkan rasa bhakti, manusia berusaha dan berupaya untuk dapat mewujudkan rasa bhakti, rasa kasihnya kehadapan Tuhan yang telah menciptakan alam semesta berserta isinya. Dalam kaitan ini, Wayan Dana (pande pembuat keris) menyatakan sebagai berikut.

Nilai pendidikan upacara dapat dilihat dari pelaksanaan Tari Dewa Ayu ini, yang tidak lain adalah sebagai kegiatan keagamaan, upacara yadnya. Rangkaian kegiatan keagamaan dilengkapi dengan sarana upakara, baik berupa banten ataupun alat-alat (uparengga) lain yang digunakan sebagai penunjang upacara. Pada saat pementasan tari Dewa Ayu ini membawa sarana atau properti berupa Keris yang merupakan simbol Purusa dan penari Dewa Ayu merupakan Simbol Predana (wawancara, 30 November 2019).

Pernayataan tersebut diatas di dukung oleh Teori Simbol; adalah suatu hal atau keadaan yang merupakan pemahaman terhadap obyek. Tujuan dan isi dari simbolisme adalah untuk menyampaikan hakekat dalam bentuk mental kultural dan spiritualisme.

\section{e. Pendidikan Apresiasi Seni dan budaya}

Tari dewa ayu merupakan ekspresi seni-religi yang menimbulkan rasa keindahan. Rasa indah adalah suatu pengalaman dari sisi psikologis dan emosional yaitu pengalaman keindahan yang akan mengantarkan seorang individu mencapai sisi psikologis transendental (Noorwatha, 2018). Menurut Ni Kadek Kartini, selaku penari tari dewa ayu, ungkapan seni dapat dirasakan oleh para penari maupun oleh warga masyarakat Desa Pemuteran, karena dengan seni tari mampu menambah kekhusukan dan kekhidmatan. Suasana kesucian membantu kesungguhan hati para penari maupun warga masyarakat Desa Pemuteran dalam sujud bhakti kehadapan Ida Sang Hyang Widhi Wasa (Tuhan Yang Maha Esa) beserta manifestasinya. Lewat keindahan tari dari sudut artistik, kerohanian, kreasi seni khususnya Tari Dewa Ayu mempunyai pengaruh langsung terhadap kepribadian yaitu kebahagiaan, kepuasan, keseimbangan, pertumbuhan, kreatifitas, kompetensi, watak, kebebasan, kondisi fisik, sosial dan sikap dari para penari akan tumbuh dan berkembangnya sikap kemandirian. Proses pembentukan kepribadian dari pementasan Tari Dewa Ayu dapat diwujudkan dari aspek keselarasan, kesucian, keseimbangan nilai yang dapat mendatangkan iklim persahabatan, mencintai sesama hidup dan dapat meningkatkan rasa kemanusiaan yang tinggi.

\section{Kesimpulan}

Tari dewa ayu merupakan tari wali yang dipentaskan pada Upacara Yadnya di Desa Pemuteran, Kecamatan Gerokgak, Kabupaten Buleleng. Upaya pelestarian Tari Dewa Ayu didasarkan pada alasan bahwa Tari dewa Ayu sebagai persembahan kepada Hyang Widi Wasa, serta untuk menjaga hubungan harmonis manusia dengan alam agar terhindar dari malapetaka. Secara umum, prosesi tari dewa ayu bisa dipilah menjadi tiga bagian (1) persembahan canang sari dan dupaoleh pemangku; (2) ngurek, yakni tahap penari yang didampingi pemangku mengalami kerauhan dengan menikam diri dengan keris yang mereka bawa; (3) tahap penyadaran penari dari kerauhan ke situasi normal. Pemangku mengambil keris dari penari untuk diberi tirta dan dibawa ke tempatnya (jeroan). Tari dewa ayu memiliki nilai-nilai pendidikan, meliputi: nilai pedidikan kebersamaan, nilai pendidikan tattwa, nilai pendidikan susila, pendidikan upacara, nilai pendidikan apresiasi seni dan budaya

Sebagai bagian dari upaya pelestarian tari wali (sakral), tradisi pertunjukan tari desa ayu dalam kehidupan masyarakat Desa Pemuteran perlu tersu dilestarikan. Nilainilai pendidikan yang terkandung dalam tari dewa ayu perlu disosialisasikan kepad generasi penerus. 


\section{Daftar Pustaka}

Bandem, I Made. 1984. "Transformasi Kesenian Dalam Pelestarian Nilai Budaya Bali" dalam Puspanjali Persembahan. Prof. Dr. Ida Bagus Mantra CV Kayumas.

Bandem, I Made. 1983. Ensiklopedi Tari Bali. Denpasar : Asti Denpasar.

BKSTI, 2017.BKSTI ub.ac.id /wp-content/upload/2017/10/keynote Speker Drajad Irianto.pdf.

Djelantik. A.A. Made 1999. Estetika Sebuah Pengantar. Bandung: Masyarakat Seni Pertunjukan Indonesia

Edy Sedyawati. 2006. Budaya Indonesia Kajian Arkeologi, Seni, dan Sejarah. Jakarta. PT Raja Grafindo Persada.

Gorda, I Gusti Gede 2002. Alat-alat Upacara Agama Hindu dalam Konteks Seni Sakral. Makalah Sarasehan Seni Sakral. Denpasar: Dinas Kebudayaan Provinsi Bali

Rai Diah Yusdarini 2014. Pertunjukan Barong Ngunying sebagai media pendidikan Agama Hinduu di Desa Pakraman Bebalang Bangli

Muliartini, Ni Nyoman 2017, Jurnal Penelitian Agama Hindu Eksistensi tari Baris IdihIdih di Desa Pekraman Patas

Noorwatha, I. K. D. 2018. Rekontekstualisasi Estetika Hindu 'Rasa' Dalam Desain Arsitektural. Mudra Jurnal Seni Budaya, 33(2), 200-208. https://doi.org/10.31091/ mudra.v33i2.351

Koentjaraningrat, 2003.Pengantar Antropologi I. Jakarta: Rineka Cipta.

Pudja, I Gede dan Tjokorda Rai Sudharta. 2002. Manawa Dharmasastra. Jakarta: Pustaka Mitra Jaya.

Ruastiti. Ni Made. 2017. Mudra Jurnal Seni Budaya. Membongkar Makna Pertunjukan Tari Sang Hyang Dedari, (Volume 32, Nomor 2, Mei 2017) https://id.m.eikipedia.org

Surayin. Ida Ayu Putu. 2002. Melangkah Ke Arah Persiapan Upakara Upacara Yadnya. Surabaya : Paramita.

Oka Sanjaya Gede. 2011. Siva Purana. Vol II. Paramita Surabaya.

Oka, I Gusti Agung.1994. Dresta Sima Agama. Denpasar: Cv. Kayumas Agung

Wiana, I Ketut. 2000. Arti Dan Funsi Sarana Persembahyangan. Surabaya : Paramita. 